\title{
MECHANICAL CHARACTERIZATION OF TRADITIONAL MASONRY IN AN HOMOGENEOUS TERRITORY: VALTELLINA
}

\author{
MATTIA SALA*, DARIO FOPPOLI ${ }^{\dagger}$, STEFANO DELLA TORRE \\ * Graduated in Building Engineering at Politecnico di Milano \\ e-mail:mattia5.sala@mail.polimi.it -Web page: http://www.polimi.it \\ ${ }^{\dagger}$ Technical director of Foppoli Moretta e Associati s.r.1. \\ Via G.F. Damiani 2, 23037 Tirano (SO) \\ e-mail: posta@foppolimoretta.it - Web page: http://www.foppolimoretta.it \\ $¥$ ABC department, Politecnico di Milano \\ (Department of Architecture, Built environment and Construction engineering) \\ Piazza Leonardo da Vinci, 32, 20133 Milano (MI) \\ e-mail: stefano.dellatorre@polimi.it - Web page: http://www.abc.polimi.it
}

Keywords : Valtellina, masonry, drystones, stones, lime mortar, Non Destructive Testing.

\begin{abstract}
The current Italian Building Code provides tables with standard values of the mechanical characteristics of existing masonry. These tables refer to specific typologies, as described, according to masonry texture. As experience suggests, the way in which the masonry is built up could really affect its structural behaviour, both in terms of mechanical properties and failure mechanisms. Furthermore, the code entrusts each Region to improve and better define these mechanical characteristics, specifically in areas where they could be regarded as homogeneous, in order to improve definitions of the quality, the behaviour and the mechanical properties with a higher degree of precision and knowledge.

Valtellina, located in the north of the Lombardy region and in the middle of the Alps, can be regarded as a homogeneous area because of its specific masonry, built up with hard rock stones and weak lime mortar. The available in-situ experimental data about this masonry typology, achieved through MDTs and NDTs, was collected, implemented and improved with additional tests to identify the relevant mechanical properties. This was aimed to classify and structurally identify this specific regional masonry typology, never analysed before.
\end{abstract}

\section{INTRODUCTION}

The assessment of historic building vulnerability is a big issue in Italy, mainly due to the fragility of the area which is often subject to devastating events, such as floods and landslides, but above all earthquakes that, in recent years, have severely affected the national territory. Natural events, although not always of high intensity, often have a devastating impact on the historical buildings, in particular from the cultural point of view, since the repairs of the damages, whenever possible, always result in an effective loss of the cultural value of the artefacts.

In Italy the attention to the structural vulnerability under the effects of natural events was drawn from the earthquake that affected the Friuli region in 1976 and further increased with the subsequent seismic events (Irpinia 1980, Umbria-Marche 1997, L'Aquila 2009, Emilia 2012 up 
to the last Amatrice-Norcia 2016 earthquake and aftershocks). These experiences highlighted two crucial area of lacking knowledge that need to be improved:

- the damage and vulnerability of masonry and buildings subjected to seismic action;

- the predictive models, mechanical interpretations and effectiveness of the interventions.

The failure of a structural system focuses on the weakest link of the structural chain: while on the one hand the design of new buildings makes this evaluation simple, on the other hand for existing structures it is difficult to properly identify the relevant mechanism.

The current Italian Building Code [1] defines the properties of the masonry through numeric tables, which classify the stone and mortar masonries on the basis of six typologies, identified by the observation of the elevation texture, and the solid brick masonries on a single category. The mechanical characteristics of the walls can also be identified on a case-by-case base by carrying out MDTs (Minor Destructive Tests) and NDTs (Non-Destructive Tests). Furthermore, the code entrusts each region to improve and better define the mechanical characteristics of the masonries, specifically in areas that can be regarded as homogeneous in order to define their quality, behaviour and mechanical properties with a higher degree of precision and knowledge.

The aim of this research is a first collection of the available in-situ experimental data referred to the area of the Valtellina region, gained through MDTs (e.g. flat-jack tests, both single and parallel) and NDTs (e.g. sonic tests). Moreover, the analyses were implemented with other methods: further sonic tests to define the masonry quality and penetrometric tests to define the

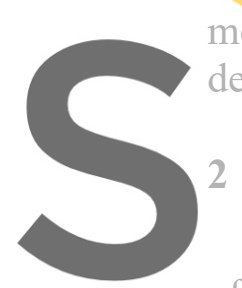
mortar properties. Data were finally processed in order
determine the masonry typology and its nelevant mechantical
2 CONSTRUCTION MA TERIALS
Valtellina, the study area, is a valley located in Lombandy, of the Alpine arc, close to the border with Switzerland. The geographical location of the valley has strongly influenced its historical and civil events: que to its key position between the South

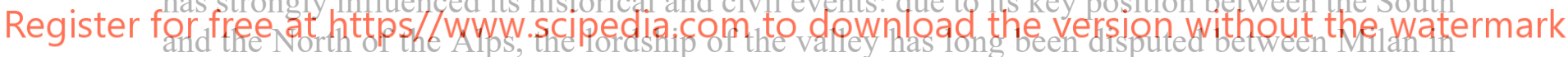

Italy and Chur in Switzerland, with alternate upheavals that have moved northward and southward the administrative and economic axis. For this reasons, this territory is a significant object of study, as it is peculiar and at the same time exemplary of the development of an area placed in "the Alps, a unique region in the centre of Europe"[2].

From a geological point of view, Valtellina is located in the western area of the Alps, characterized by silicate rocks, rather than the dolomitic and limestone ones which are present in the eastern area. The valley is located exactly along the Tonale fault, an imposing tectonic dislocation that runs from East to West in the central part of the Italian Alps, which means that most of the rocks placed along the territory are of metamorphic origin. The intrinsic characteristics of the metamorphic rocks (first of all their stratification) strongly influence the masonry construction techniques in the area. On the other hand, the relative difficulty in finding limestone rocks affects (in a negative way) the availability of lime mortars.

The historical buildings are usually made with the rock materials that were easily available (close to the construction site), which required minimal processing and allowed a fast use. Only for the buildings with iconic importance, as churches or noble palaces, the stones were sometimes taken at a greater distance and often selected and processed with a greater care in 
order to underline the prominence of these building. Anyway, in the Valtellina context this was mainly limited to the production of decorative elements such as mouldings, columns and pilasters. As for the type of stones used, Valtellina masonries can be classified according to three types:

> Rough-stone masonries (Fig. 1): shapeless pieces of stone material, obtained exclusively by splitting the rock mass or collecting the rock pieces lying on the ground; their shape, often multifaceted irregular with sharp edges, allows for stable positioning of the components to be obtained even without the use of mortar to build drystone walls;

> Rough-hewn stone masonries (Fig. 1): also called "drafts", they have dimensions which are generally similar to the rough ones; they have a defined shape with a tolerance due to the surfaces processing;

> Cut-stone masonries (Fig. 1): generally coming from compact rocks characterized by a good processing capability to be regularized with the squaring and finishing processes.
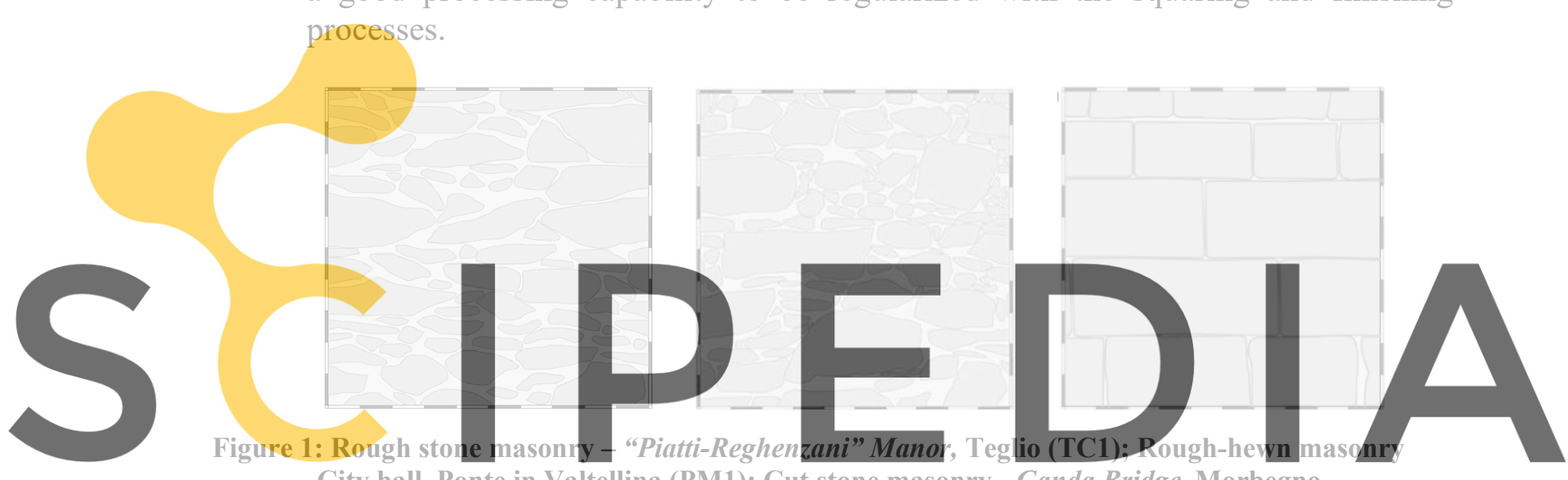

- City hall, Ponte in Valtellina (PM1); Cut stone masonry - Ganda Bridge, Morbegno

Register for free at https/Awww scipedia.com to download the version without the watermark On the one side, as already stated, the scarce availability of easily workable stones limited the use of cut or carved stones to elements of particular value. The already mentioned predominant presence of metamorphic rocks naturally provided stones suitable for the construction. Indeed, because of their elongated shape and easiness of splitting according to the stratification plans, the lithic elements taken from metamorphic rocks are definitely suitable for the construction of the traditional wall texture.

The production of mortar is conditioned by the availability of suitable binders, to be used individually or in a mixture with each other. For this purpose, in the Valtellina area there are only very localized limestone outcrops. Extensive limestone outcrops, belonging to the group of the main Dolomia, can be found only in upper Valtellina, around Bormio.

The prevalent use of rough stones would lead to suppose the need of high mortar quantities inside the walls; however, the elongated conformation of the metamorphic stones implies that the rocks can be laid in rather horizontal courses, thus obtaining internal contact points and limiting the use of binding: this construction technique also derives from the tradition of the Valtellina walling method. To evaluate this circumstance, the front elevation of the walls was scanned in order to define the mortar quantity, which average percentage, referred to the whole 
masonry, was found to be around $25 \%$. It should be noted that this is only a qualitative estimation: due to wall texture the actual mortar quantity in the section can be different from the quantity calculated on the basis of the front elevation.

\section{CONSTRUCTION TECHNIQUES}

The construction techniques used in Valtellina are of course conditioned by the type and quality of the rocks and by the poorness of mortar used. Techniques that use rough or roughhewn stones are defined "complex", as the arrangement has to follow precise rules and a careful selection of the stones to be used [3]. Techniques that use cut stones, called "ashlars", are defined "simple", as the parallelepiped shape deriving from shaping processes allows a simpler placement, with a lower quantity of mortar. Following the scarce use of cut-stones elements, the masonries detected on the territory of study are mainly made with "complex" techniques. It is worth noting that cut stones are often used only in the external fronts, giving a good look but no warranty that in the interior of the wall stones are laid in a correct way.

\subsection{Drystone walls}

Valtellina has a very peculiar "cultural" landscape, the most evident expression of which is the extensive terracing that characterizes the Rhaetian slope at the lowest altitudes, approximately up to $1000 \mathrm{~m}$ above sea level. The available information reports an historical overall terraced surface than $1 / 6$ of its maximu of retaining walls made
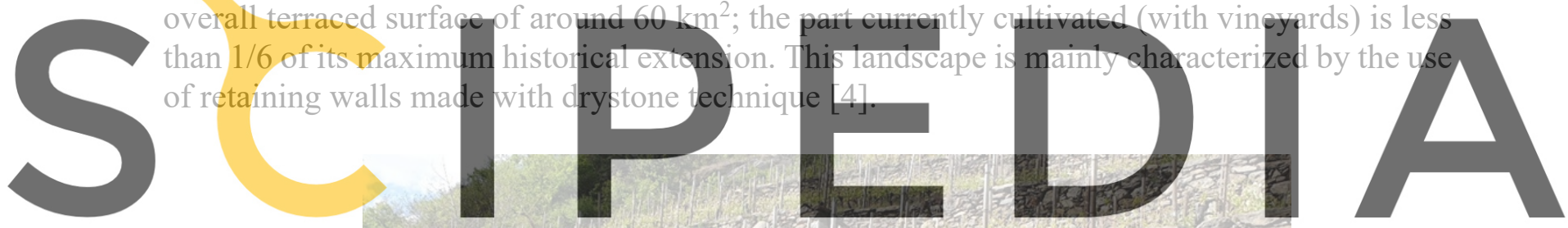

Register for free at https//www.scipedia.com to download the version without the watermark

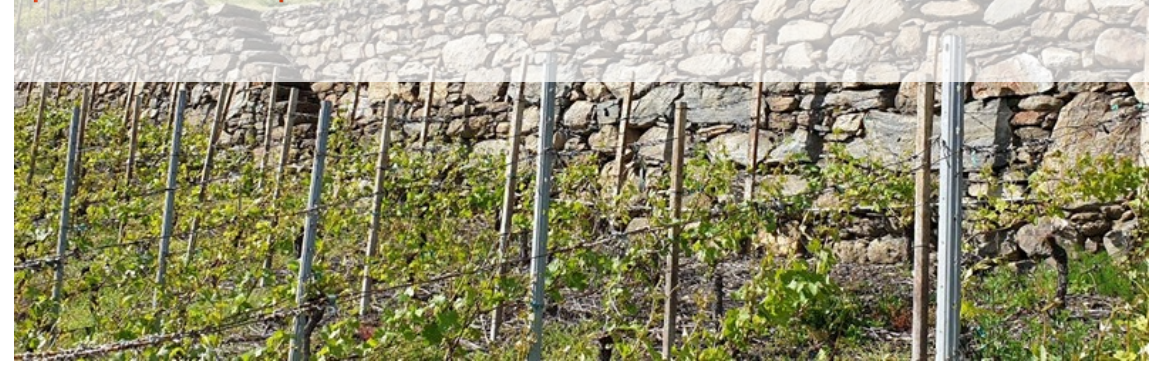

Figure 2: Typical facing of a drystone wall of the Valtellina terraces

In the territorial context of this study the characteristics of drystone masonry (Fig. 2) have strongly permeated even the techniques of stone and mortar ones: that's why useful information for the ordinary buildings can also came from the study of the construction techniques of the drystone masonry. On the basis of the technical literature the stability of a drystone wall is strongly related to the experience and to the skill of the mason, who has to respect six specific "rules of art" [5]: proper setting of the foundation (generally with low depth), vertical offset of the joints to obtain the optimal distribution of the weights; horizontality of the stone courses; 
balancing of the stones; transversal connections to ensure a correct interlocking of the walllayers and finally particular attention to the connection of the orthogonal walls (cornerstones).

\subsection{Masonry walls}

The main part of Valtellina buildings, even those that can be classified as cultural heritage (churches, palaces and rural nuclei) are characterized by a lithological variety and by the use of construction techniques almost indistinguishable from the drystone walls, although generally encompassing the use of mortar (Fig. 3).
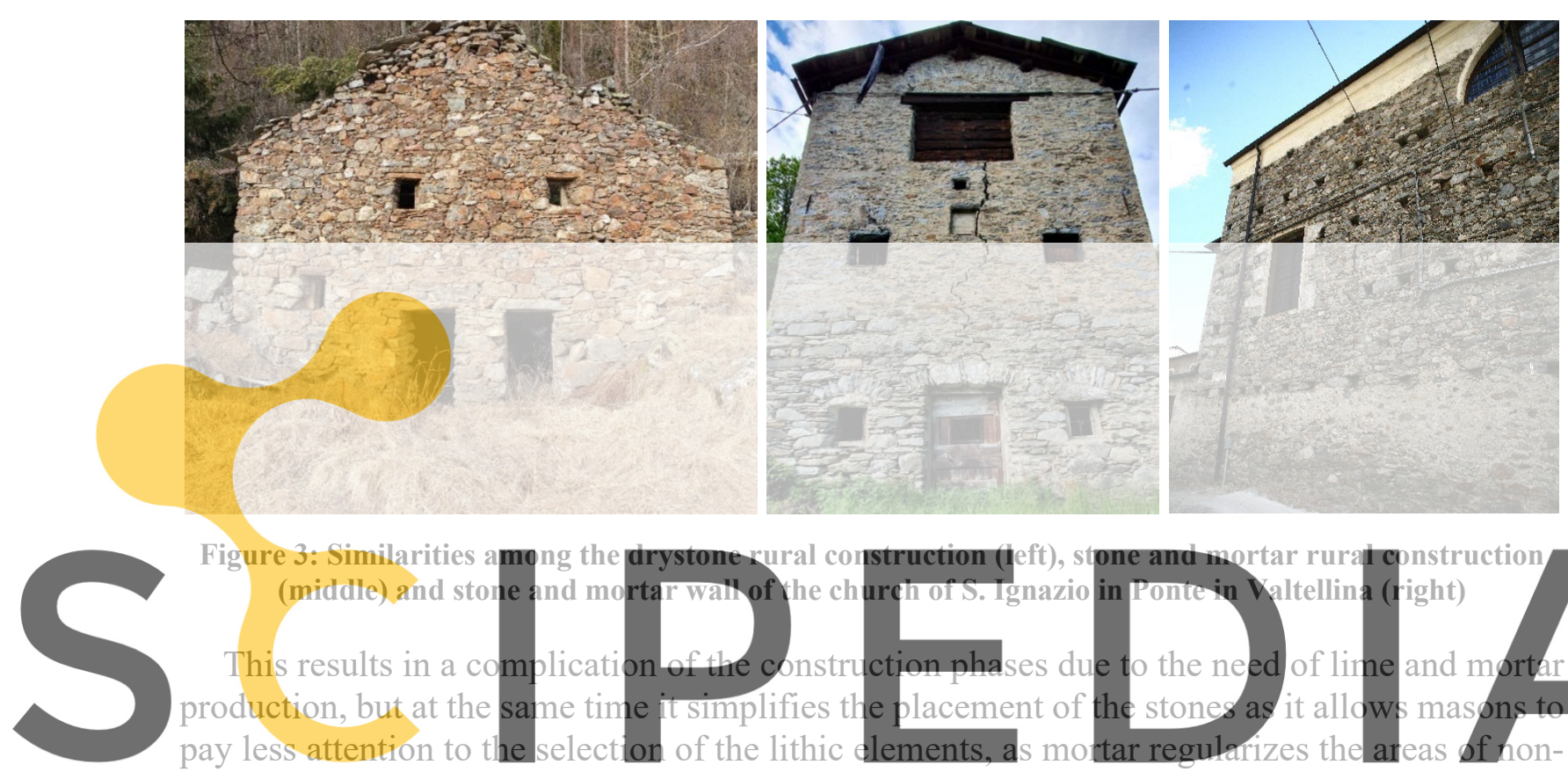

Figure 3: Similarities am
(middle) and stone

This results in a com

production, but at the same tim

pay less attention to the selection
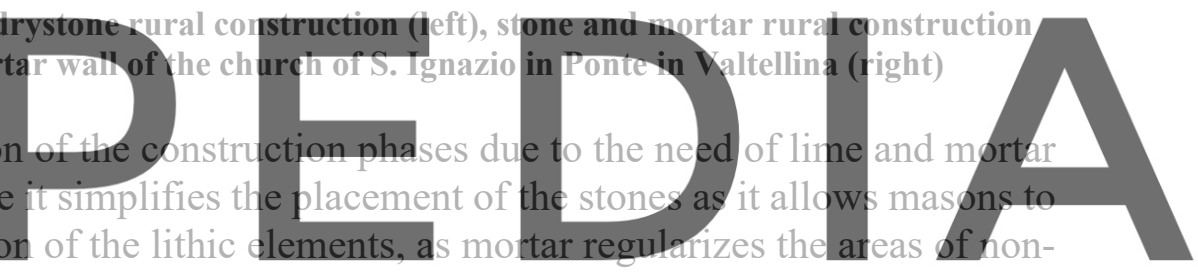

contact between the stones. However, the "rules of art" mentioned above for drystone masonry

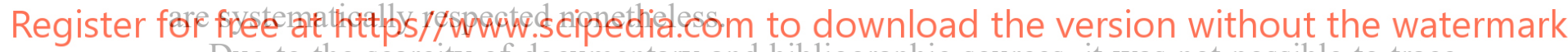

Due to the scarcity of documentary and bibliographic sources, it was not possible to trace

back a proper description of construction techniques in Valtellina: for this reason, a detailed

analysis of the characteristic of two buildings historically representative of the local context was carried out: S. Ignazio Church at Ponte in Valtellina and Masegra Castle at Sondrio.

For the castle, the lithological variety of the stones shows a close relevance to the territorial context of the nearby Valmalenco, upstream of the Mallero river that flows in the nearby of the building; some blocks are also presumably attributable to the glacial deposits present on the Rhaetian slope. For this reason, the materials are of a crystalline nature, metamorphic or intrusive. The foundation masonry walls are laid out with sub-horizontal courses consisting in stone of various lithology and size (mainly gneiss and serpentine) and lime mortar of varying colour and grain size. The elevation walls are also characterized by sub-horizontal layers in stone blocks and mortar courses with large thickness.

The systematic observation of the wall facing masonries of the castle and of the other cases of study highlights that, regardless of the building periods, the masonries can be sorted into two types (Fig. 4):

- masonries made with stones laid with disordered texture,

- masonries made with stones laid with rather horizontal courses (good-texture). 
These masonries can be built both with rough or rough - hewn stones, with the latter being predominant in the second type.
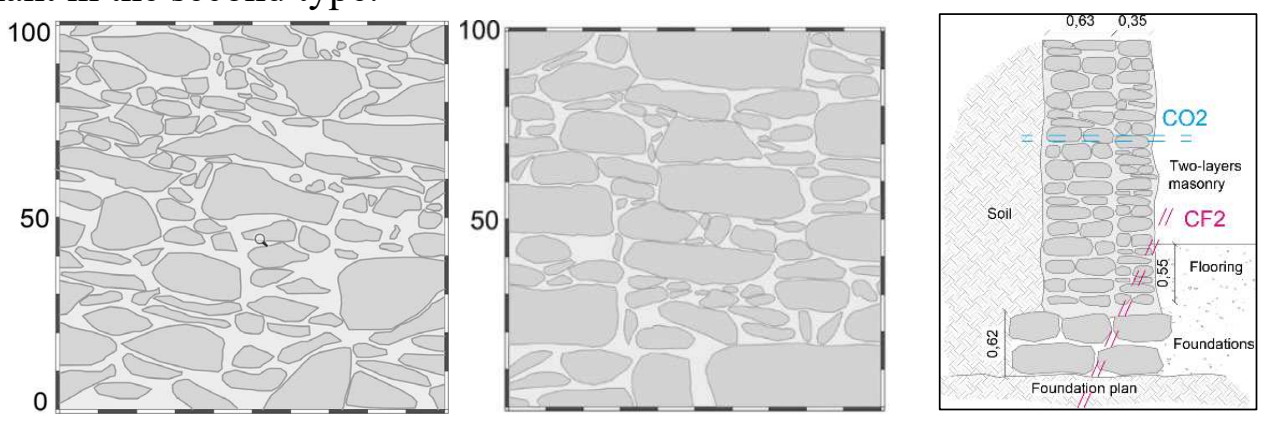

Figure 4: Masonry wall facing and section of the Masegra Castle masonries

\section{DATA COILECTION}

The analysis of the masonry mechanical characteristics is a fundamental basis for the correct modelling of the structural behaviour of the building. Both for existing buildings [1] and for cultural heritage ones [7] Non-Destructive (NDTs) and Minor Destructive (MDTs) tests allow the quantitative determination of these characteristics. It is important to underline, how the Guidelines [7] explicitly state, that "Non Destructive diagnostic Techniques of indirect type, such as sonic and ultrasonic tests, assess the homogeneity of the mechanical parameters ... but

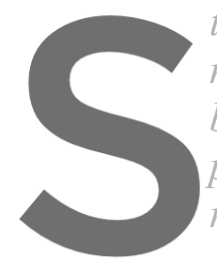
they do not provide

measurement of the med

be performed only thro

portions. Calibrations

reduce the invasiveness

The numerical anatys
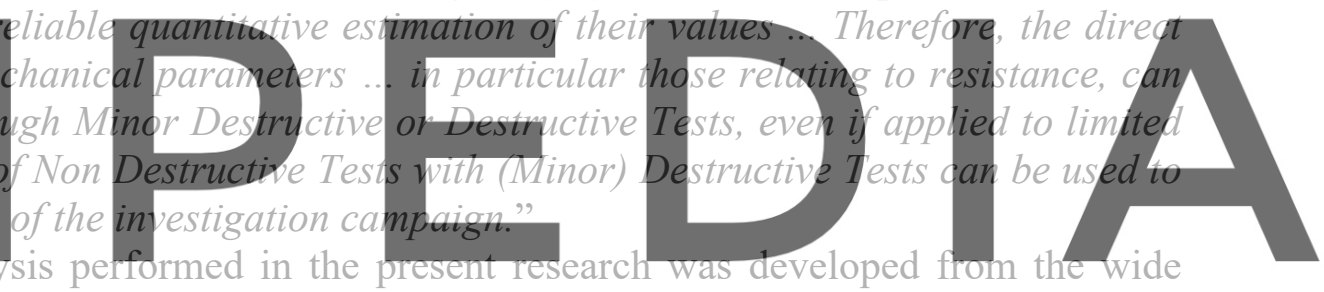

database made available by the company Foppoli Moretta \& Associati consulting engineers and

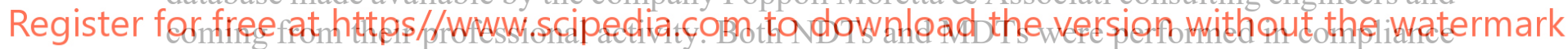
with the standards listed in Table 1.

Table 1: Reference standards for the tests performed

\begin{tabular}{lll}
\hline & \multicolumn{1}{c}{ TEST } & \multicolumn{1}{c}{ CODE } \\
FJs & Single flat jack & $\begin{array}{l}\text { ASTM C 1196-14 (2014). Standard test method for in situ } \\
\text { compressive stress within solid unit masonry estimated using the } \\
\text { flatjack method. }\end{array}$ \\
\hline FJp & Parallel flat jacks & $\begin{array}{l}\text { ASTM C 1197-14 (2014). Standard test method for in situ } \\
\text { measurement of masonry deformability properties using the flatjack } \\
\text { method. }\end{array}$ \\
\hline SO & Sonic test & $\begin{array}{l}\text { UNI EN 12504-4 (2005), Prove sul calcestruzzo nelle strutture - } \\
\text { Parte 4: Determinazione della velocità di propagazione degli } \\
\text { impulsi ultrasonici. }\end{array}$ \\
\hline PT & Penetrometric test & $\begin{array}{l}\text { Jurina, L. (2007), La caratterizzazione meccanica delle murature } \\
\text { parte prima: prove penetrometriche. Politecnico di Milano - DIS }\end{array}$ \\
\hline CO & Corings & $\begin{array}{l}\text { UNI EN 12504-2 (2019), Prove sul calcestruzzo nelle strutture - } \\
\text { Parte 1: Carote - Prelievo, esame e prova di compressione. }\end{array}$ \\
\hline
\end{tabular}


The available dataset has been integrated with experimental tests, specifically carried out for this work, which have been marked in bold in the following Table 2.

Table 2: Tests performed

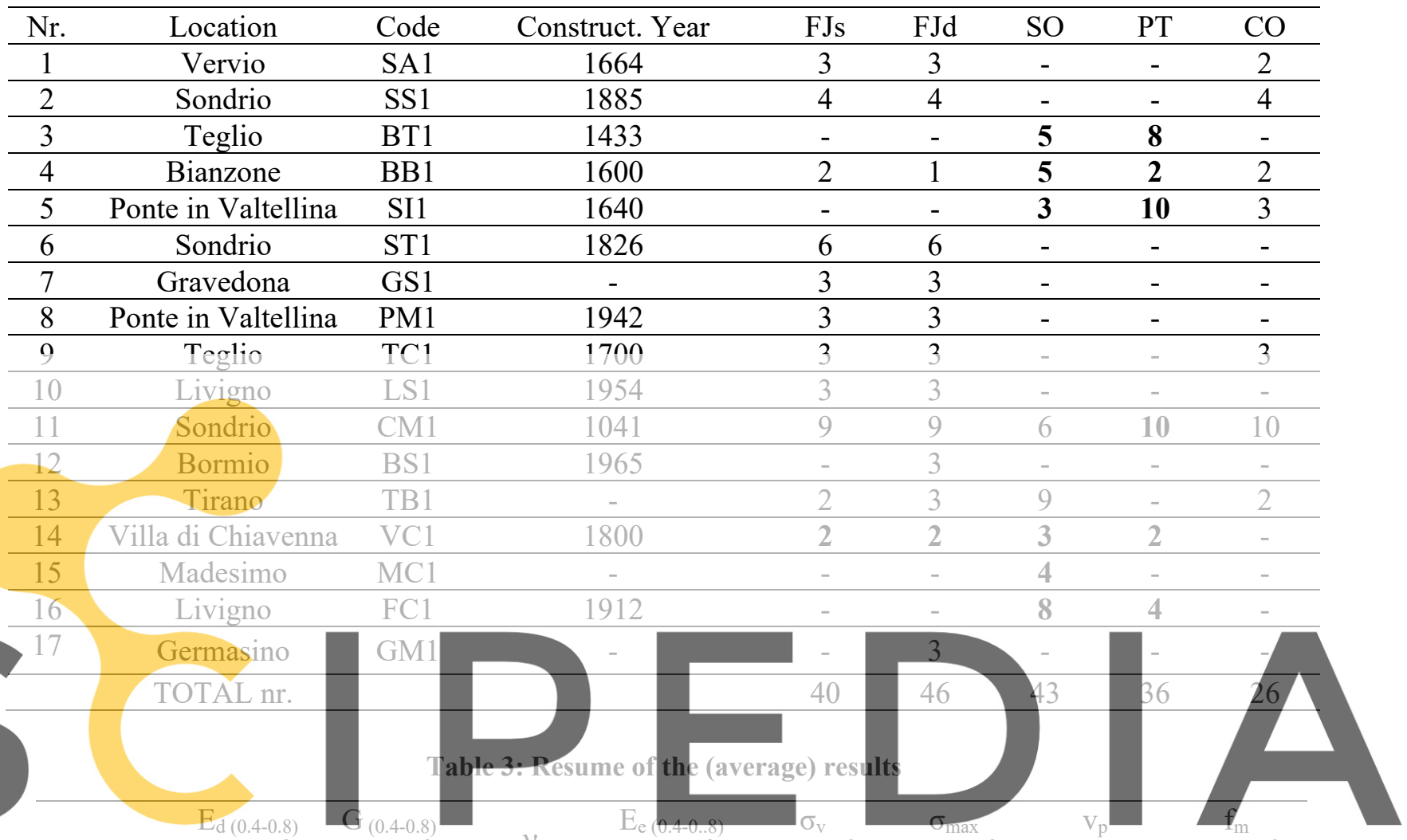

Building $\left[\mathrm{N} / \mathrm{mm}^{2}\right] \quad\left[\mathrm{N} / \mathrm{mm}^{2}\right] \quad \vee \quad\left[\mathrm{N} / \mathrm{mm}^{2}\right] \quad\left[\mathrm{N} / \mathrm{mm}^{2}\right] \quad\left[\mathrm{N} / \mathrm{mm}^{2}\right] \quad[\mathrm{m} / \mathrm{s}] \quad\left[\mathrm{N} / \mathrm{mm}^{2}\right]$

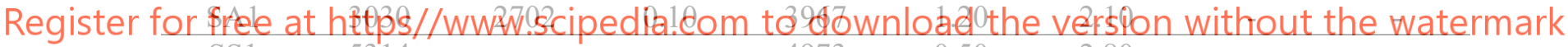
SS 1

\begin{tabular}{ccccccccc} 
BT1 & - & - & - & - & - & - & 1590 & 1.80 \\
\hline BB1 & 5263 & - & - & 7562 & 0.60 & 2.40 & 1534 & 1.80 \\
\hline SI1 & - & - & - & - & - & - & 1603 & 1.70 \\
\hline ST1 & 4076 & 1069 & 0.10 & 5262 & 0.40 & 2.50 & - & - \\
\hline GS1 & 3724 & 710 & 0.20 & 5433 & 0.50 & 2.90 & - & - \\
\hline PM1 & 2119 & 963 & 0.10 & 3095 & 0.50 & 2.30 & - & - \\
\hline TC1 & 1095 & 415 & 0.50 & 2564 & 0.50 & 1.50 & - & - \\
\hline LS1 & 1340 & 629 & 0.10 & 2698 & 0.40 & 2.00 & - & - \\
\hline CM1 & 2744 & 1059 & 0.30 & 5582 & 0.60 & 3.10 & 2277 & 1.70 \\
\hline BS1 & 11142 & - & - & 14213 & - & 4.00 & - & - \\
\hline TB1 & 2256 & 1064 & 0.10 & 3651 & 0.30 & 2.70 & 1655 & - \\
\hline VC1 & 4444 & 1893 & 0.20 & 4829 & 0.60 & 4.00 & 2786 & 1.10 \\
\hline MC1 & - & - & - & - & - & - & 1917 & 1.50 \\
\hline FC1 & - & - & - & - & - & - & 2493 & 1.60 \\
\hline GM1 & 721 & 313 & 0.20 & 1802 & - & 1.40 & - & - \\
\hline
\end{tabular}


Numerical data taken from these tests have been processed to obtain the most significant mechanical characteristics of the masonries, as follow:

- Single flat jack [9], [10]: masonry compressive stress state $\left(\sigma_{\mathrm{v}}\right)$;

- Double flat jack [9], [10]:

$\circ$ deformability module $\left(E_{d}\right)$, calculated at the first loading stage;

- tangential deformability module $(\mathrm{G})$, calculated at the first loading stage;

- Poisson coefficient $(v)$, calculated at the first loading stage;

$\circ$ elastic module $\left(\mathrm{E}_{\mathrm{e}}\right)$, calculated at the first unloading stage;

- maximum compression strength reached for the masonry $\left(\sigma_{\max }\right)$;

- Sonic test [10], [11]: elastic sonic wave propagation velocity $\left(\mathrm{v}_{\mathrm{p}}\right)$ inside the masonry;

- Penetrometric test on mortar [12]: compression strength of the mortar ( $\left.f_{m}\right)$.

The values of the average mechanical properties, determined for each of the buildings analysed, are summarized in the previous Table 3.

\section{DATA ANALYSIS}

The collected data is a significant statistic base that allows a relevant analysis both with reference to the single test and by matching the results of different methods in order to identify the significant characteristics. By way of example, in Graph 1 the stress vs. strain curve obtained from the double flat jacks tests performed at Masegra Castle (CM1) are plotted: the mechanical characterization suggests grouping the samples into two typologies.
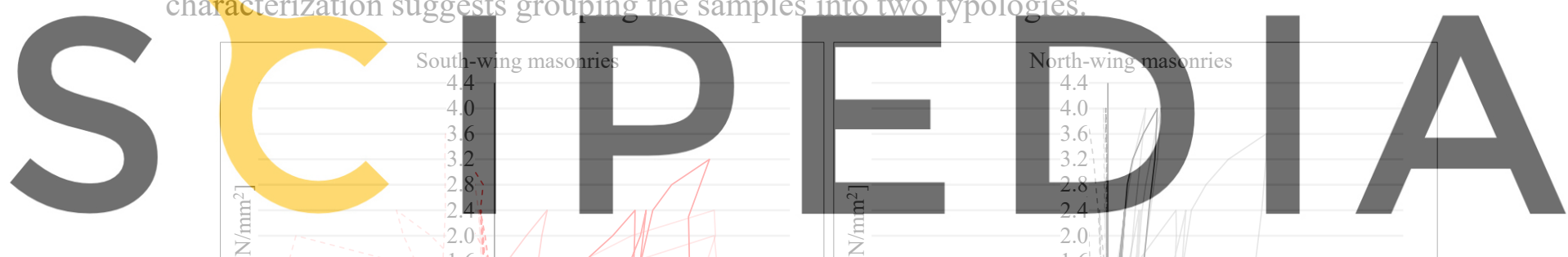

Register for fre at https//www.scipedia.com to download the version without the watermark

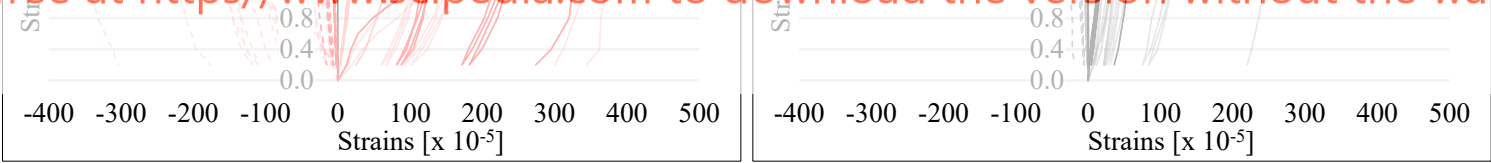

Graph 1: Stress-strain relationship of the castle masonries - South-wing (red) \& North-wing (black)

Further analyses highlighted a linear correlation between the deformability modules $E_{\mathrm{d}[0.4-8]}$ calculated at the first load stage and the elastic modulus $E_{e}$ calculated at the first unloading stage. The draft data provides a correlation with $\mathrm{R}^{2} \cong 77 \%$, by purging them from some values with little reliability allow to give up to $\mathrm{R}^{2} \cong 92 \%$, indicating a very good correlation.

Based on the above considerations, the frequency of the deformability modules of the single tests were plotted in Graph 2. It is a matter of fact that the Valtellina masonries have a very high variance of modules, therefore it is difficult to make considerations on this draft data. Following the previous typological and mechanical observations, the walls were divided in compliance with the description of the elevation texture between "masonry with disordered texture" (type I, n. 25 reference tests) and "masonry with rather horizontal courses" (type II, n. 15 reference 
test). The higher module values $E_{d}[0.4-0.8]>5000$ were identified as anomalous and excluded from the analysis.

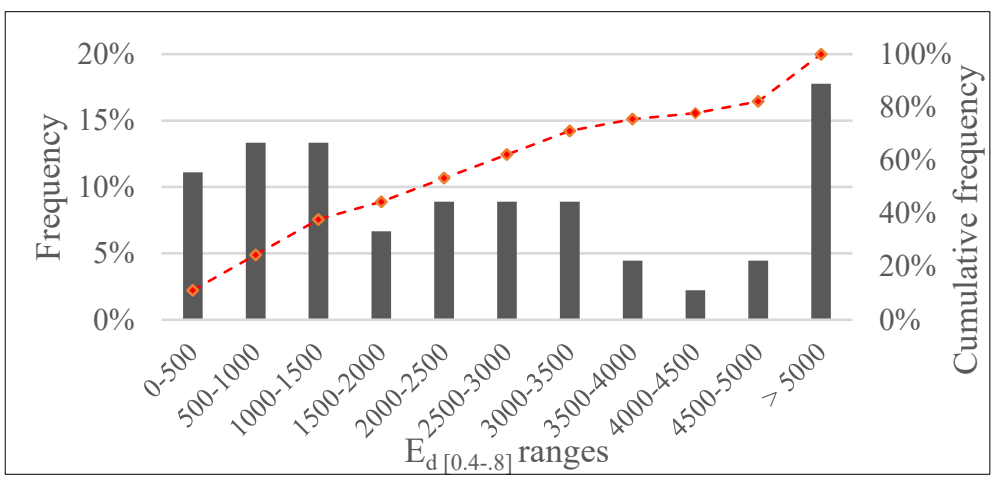

Graph 2: Deformability module frequency distribution - percentage and cumulative frequency

This way it was possible (Graph 3 left) to draft two normal distribution curves referred to type I and type II and to calculate the respective $25 \%$ and $75 \%$ percentiles. It can be noted that the disordered masonries have an average value $\mathrm{E}_{\mathrm{d}[0.4-0.8]}=1888 \mathrm{~N} / \mathrm{mm}^{2}$, while the good-texture masonries have an average value $\mathrm{E}_{\mathrm{d}[0.4-0.8]}=3571 \mathrm{~N} / \mathrm{mm}^{2}$. The values calculated according to the different typology are summarized in Table 4. It has to be noted that the average Ed [0.4-0.8]

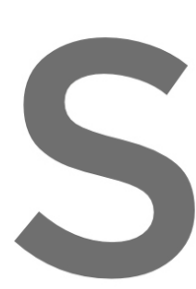
values found are not typologies identified at

Register for free at https//www.scipedia.com to download the version without the watermark
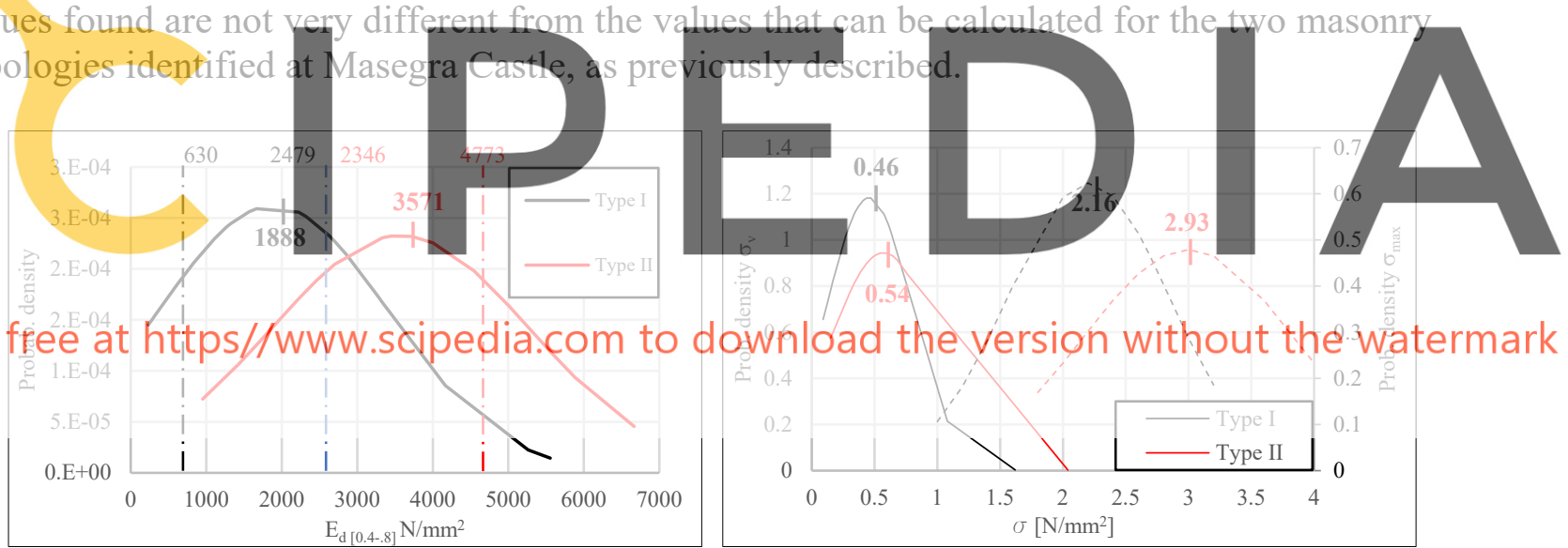

Graph 3: Normal distribution curve of deformability modulus and of $\sigma_{\mathrm{v}}$ and $\sigma_{\max }$

The two distribution curves (type I and type II) intersect for a good part of their development, focusing not only on the type of stone used, but also on the masonry construction technique: walls with good texture, which have a high contact among the stones (little mortar quantity) have a higher elastic modulus. Conversely the strength of the mortar is not a discriminating factor because it presents no relevant variations.

Analysing the overall masonry stress state it is possible also to note that in any case the current compression stress does not exceed the maximum detected one (Graph 3 right): thus, the average value of the safety coefficient $\gamma=\frac{\sigma_{\max }}{\sigma_{v}}$ can be calculated, which turns out to be quite satisfactory in the test load conditions (means static with only own-weights). 
Table 4: Resume of the mechanical characteristics of the masonry, according to the type

\begin{tabular}{|c|c|c|c|c|c|c|c|c|}
\hline $\begin{array}{c}\text { Masonry } \\
\text { type }\end{array}$ & $\begin{array}{l}\mathrm{E}_{\mathrm{d}(0.4-0.8)} \\
{\left[\mathrm{N} / \mathrm{mm}^{2}\right]}\end{array}$ & $\begin{array}{c}\mathrm{G}_{(0.4-0.8)} \\
{\left[\mathrm{N} / \mathrm{mm}^{2}\right]}\end{array}$ & $\begin{array}{c}v \\
{[-]}\end{array}$ & $\begin{array}{l}\mathrm{E}_{\mathrm{e}(0.4-0.8)} \\
{\left[\mathrm{N} / \mathrm{mm}^{2}\right]}\end{array}$ & $\begin{array}{c}\sigma_{\mathrm{v}} \\
{\left[\mathrm{N} / \mathrm{mm}^{2}\right]}\end{array}$ & $\begin{array}{c}\sigma_{\max } \\
{\left[\mathrm{N} / \mathrm{mm}^{2}\right]} \\
\end{array}$ & $\begin{array}{c}\mathrm{v}_{\mathrm{p}} \\
{[\mathrm{m} / \mathrm{s}]}\end{array}$ & $\begin{array}{c}\mathrm{f}_{\mathrm{m}} \\
{\left[\mathrm{N} / \mathrm{mm}^{2}\right]}\end{array}$ \\
\hline I & 1888 & 750 & 0.18 & 3578 & 0.46 & 2.16 & 1332 & 1.45 \\
\hline II & 3571 & 1344 & 0.09 & 5360 & 0.54 & 2.93 & 2443 & 1.41 \\
\hline
\end{tabular}

A further attempt was made to divide the masonry characteristics by type of construction (civil, ecclesiastical and noble buildings), by location (higher, middle and lower Valtellina) and by construction period, but no significant result was obtained, proving that there was no real difference in the construction techniques among the mentioned classes. The only qualitative observation was that the noble buildings are mainly made with disordered stone masonry and that the buildings, from the 20th century onwards, are mainly built with rough-hewn ashlars.

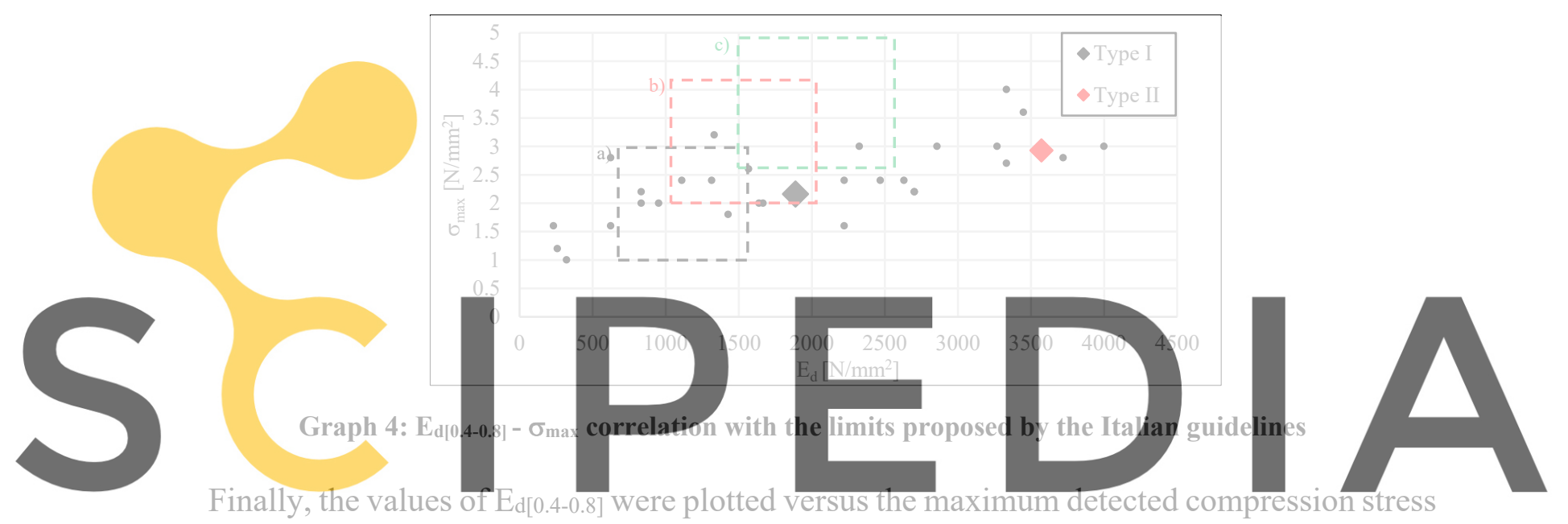

Finally, the values of Ed[0.4-0.8] Were plotted versus the maximum detected compression stress

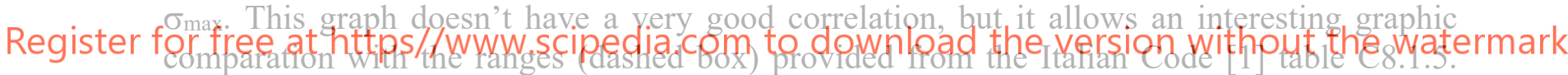
These ranges were be compared to the values provided from the current anaylsis (clash-dot lines): for the masonries classified as type $I$, the identified Valtellina masonry proved to be stiffer than the values provided by the code. The available data are of course limited to the walls that were brought to compression failure during the tests.

\section{CONCLUSIONS}

The masonry construction techniques in Valtellina are strictly connected to the historical, cultural and geological features of this territory. On the basis of more than 190 NDTs and MDTs, this paper proposes a preliminary classification of the typical local masonry walls (made with stone and mortar) into two typologies: "masonry with disordered texture", "masonry with rather horizontal courses". The data analysis allows the estimation of the typical mechanical characteristics and their variation. The type of construction, the location and the construction period do not seem to be influential parameters in this analysis. This work can be regarded as a first effort, as suggested the Italian Building Code, for the definition of the mechanical characteristics of the typical masonry that can be regarded as homogeneous in a specific area of Lombardy region. 


\section{ACKNOWLEDGMENTS}

The research described in the present paper was carried out within a master thesis work and under the R\&D plan "In Situ Testing of Masonry Characteristics" developed by the Italian company "Foppoli Moretta e Associati consulting engineers" with their own resources and without any public grant.

Thanks to prof. Maria Adelaide Parisi for her advice, and to all the clients who requested and allowed the tests necessary for the data collection, particularly the municipalities of Sondrio and Bianzone and the Polo Museale of Lombardy.

\section{REFERENCES}

[1] Ministero Infrastrutture e Trasporti. (2019). Istruzioni per l'applicazione dell'"Aggiornamento delle "Norme tecniche per le costruzioni"» (Guidelines for the Application of Italian Building Code for Constructions)

[2] Bätzing Werner (2003). Die Alpen - Geschichte und Zukunft einer europäischen Kulturlandschaft. Verlag C.H. Beck, München 2003

[3] Mannoni, T. (1997). Il problema complesso delle murature storiche in pietra, in Archeologia dell'architettura, numero II, Firenze: All'insegna del giglio.

[4] Foppoli, D. (2019). Le Costruzioni in Pietra a Secco nel Paesaggio Culturale Valtellinese. Tirano, Notiziario Istituto Archeologico Valtellinese n. 17, Sondrio 2019.

[5] Bretto, G. (2018). L'esperienza Ossolana ed il contesto internazionale. Tecnologia e lessico della pietra a secco. In Paesaggi Terrazzati: Scelte per il Futuro (pp. 317-326). Regione del Veneto.

[6] Armanasco A., Foppoli, D. (2016). Diagnostic tests vs structural models: the utility of the comparision. Proceedings of 11th International Conference on non-destructive investigation for the diagnostic and conservation of cultural heritage (Art'14) Madrid

[7] Ministero Infrastrutture e Trasporti. (2011). Linee Guida per la valutazione e riduzione del rischio sismico del patrimonio culturale con riferimento alle norme tecniche (Guidelines for the Evaluation and Reduction of seismic Hazard for Cultural Heritage Buildings)

[8] Armanasco A., Foppoli D. (2014), Diagnostic tests vs structural models: the utility of the comparison, Proceedings of 11th International conference on non-destructive investigations and microanalysis for the diagnostics and conservation of cultural and environmental heritage (Art'14). Madrid

[9] Avila L., Vasconcelos G., Lourenço P. B. (2018), Experimental seismic performance assessment of asymmetric masonry buildings, Engineering Structures, Volume 155, pp. 298-314

[10] Binda L., Cantini L., Cardani G., Saisi A., Tiraboschi C. (2007) Use of Flat-Jack and sonic tests for the qualification of historic masonry. In: 10th North American masonry conference. St. Luis, Missouri, USA

[11] Podestà s., Scandolo L., Brignola A. (2013). Prove soniche per la caratterizzazione della monoliticità trasversale di pannelli murari. ReLUIS-DPC 2010 2013. ReLUIS

[12] Jurina, L. (2007). La caratterizzazione meccanica delle murature parte prima: prove penetrometriche. Politecnico di Milano - Dipartimento di Ingegneria Strutturale. 